\section{Broad and deep}

$\mathrm{O}$ n a July morning, I sat, notebook in hand, with three junior medical students, sweat trickling in our hairlines. The heat was oppressive under the plastic tarp that served as a roof on this makeshift kitchen on the banks of the Bagmati River in Kathmandu.

I was here as a family doctor, with two community health researchers from the Faculty of Medicine at Memorial University in St. John's, Newfoundland and Labrador, and its International Summer Institute for Global Health Training. Our job as teachers was to help students explore the social determinants of health: questions such as how gender, wealth, power, access to clean water and healthy food affect one's ability to be well or sick. Talk like this can seem remote and hypothetical in a classroom; this was our chance to explore just how real it all was.

Knowing that the students, being mostly middle-class Canadians, might be overwhelmed by the poverty they would see, I fell back on my pre-medical school days as a journalist and asked each of them to focus on one individual in front of them. Not that any one story could ever represent the whole community, but perhaps by focusing on details, our students would stay grounded and focused on problemsolving, rather than drifting off into despair. They would need this skill as doctors in a few years.

So there we were, sitting on wooden chairs, our milk chai cooling in plastic cups on the earthen floor as women from this temporary community filed in to tell us their stories. I call the community temporary, because my own middleclass Canadian sensibilities prevent me from calling it what those who live there call it: a slum. Or, in Nepali, a basti. This particular basti - and there are many in Kathmandu - is called Pauroti Basti, the "leavened bread" slum.

The first woman to speak through our translator, Syra, was S. Fifty-nine years old, with a head of wavy black hair, S. tucked up her flawless red sari

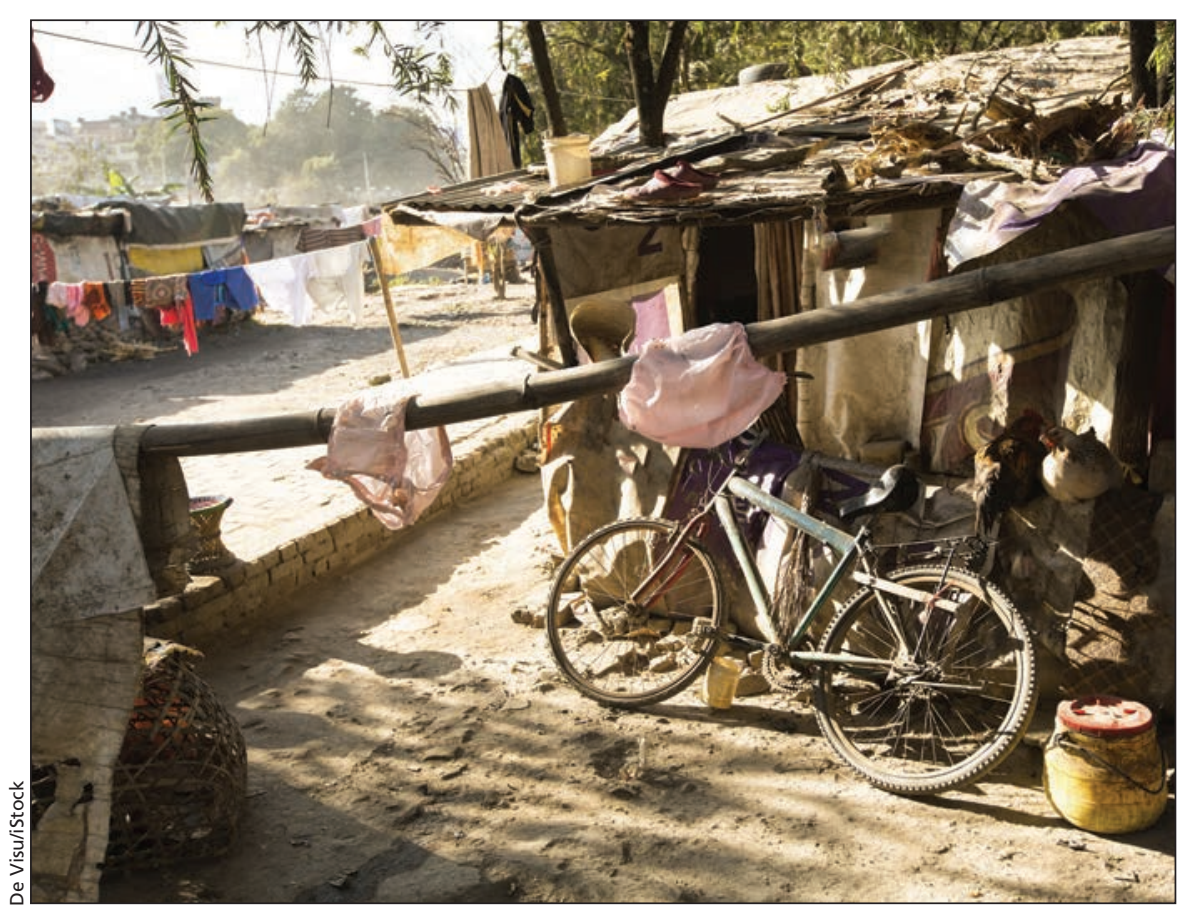

and sat down on a piece of wood the size of two decks of playing cards. She was born in a village in eastern Nepal. When she married, she went to live with her husband at his home near the local river. When the river flooded and wiped out their home, they moved to the city. They rented a flat for a time, until her husband became ill. When his insurmountable medical bills meant they could no longer afford their rent, the family had to go live in the basti. That was nine years ago.

S. bore 14 children, but five died before their first birthday. She has a son in Pauroti who has a well-paying job working for the government as a garbage collector. He earns 8000 rupees - about 80 US dollars - per month. We are surprised to learn that a government worker lives in the basti. However, to rent a flat in Kathmandu costs about 4000 rupees per room per month; S. says their extended family of 10 would need two rooms, which would cost her son's entire salary, with nothing left over for food, clothes or medicine. S. sometimes gets work carrying bricks but earns only 150-200 rupees per day - about two US dollars. So they continue to live in a house made of cast-off bamboo poles and tarps.

There were other women who spoke above the background lull of chickens and rogue children, of cell phones ringing, and of many busy voices: J., who told us about the morning of Wednesday, May 8, 2012, when thousands of Nepalese police crept in with bulldozers, tear gas and rubber bullets. As dawn broke, the soldiers rolled in, flattening 250 homes, and taking men, women and children into custody. When the women and children were released at 8 o'clock that night, they went straight back to the basti because they had nowhere else to go. Everything was gone, so they slept outside under the open sky. When the men were released the next day, they started the slow process of rebuilding. For six months, police prevented them from putting roofs on their houses, so at night they would stretch tarps to keep their children dry, and before daybreak, they'd remove the tarps again.

Our time with the women was short, but before we left, they wanted to give us a tour of the basti. We passed drinking water tanks, filled weekly by an 
international nongovernmental organization; the kitchen gardens and flocks of domestic chickens and ducks; the houses, that, with their bamboo skeletons and patchwork tarps, seem impossibly rickety to Canadian eyes, but manage to provide some shelter from the heat and rain for hundreds of men, women and children. There is a daycare and a children's lunch program that provides hot meals and fresh milk. Resilience lives in the basti, found in the sturdiness of the women and in the abundance of their many gardens. Even in the name of the community. Pauroti: bread (the staff of life), risen.

We had asked the students to listen for specific stories to help them to avoid getting lost in the vastness of history, politics, language and despair, but, back home in Canada, questions nagged me: What did the people of Pauroti get out of our visit? What did the students get out of it? Why did I come home needing so badly to share what I saw there?

My confusion ballooned when I happened to pick up a copy of Let Us Now Praise Famous Men (1941). In the preface to this pictorial and narrative story of sharecroppers in the American
South during the dustbowl years, author James Agee writes to his photographer collaborator, Walker Evans:

It seems to me curious, not to say obscene ... to pry intimately into the lives of an undefended and appallingly damaged group of human beings ... for the purpose of parading the nakedness, disadvantage and humiliation of these lives, in the name of science, of "honest journalism" ... of humanity, of social fearlessness.

There it was. Was that what I was doing as a teacher? Is that what I have done just now as a writer?

We wanted the students to listen for stories because we thought it would help them understand. What I came away with was a powerful sense that the people of the Pauroti had been erased from history simply because they are poor. Beyond their illness and deprivation, I was gutted by the knowledge that their community could be razed by heavy machinery, their bodies and minds injured with tear gas and rubber bullets, and life beyond the perimeter would go on without missing a beat. Of course, this happens every day somewhere in the world. But those people haven't gifted me with their stories.

A brilliant radio documentarist, Chris
Brookes, once told me that good stories are either broad or deep. I think any human endeavor starts broadly: we need to survey the horizon to know where we are. But sitting still for a time and situating one story in the big picture - be it a stranger's story overheard on the subway, or read in the newspaper, or even a medical presentation - is the deepening work. It's a difficult and awkward habit of mind that requires both focus and peripheral vision. In medicine, we call that being patient-centred. In journalism, we call it providing context.

But really, isn't it all the same thing? As a doctor, I'm compelled to tell about $\mathrm{S}$. and J. because their experiences provide depth to the public health story of the Pauroti basti. As a writer, I want to honour their lives and strength. I have to tell their story because they can't tell it themselves; yet they exist, like you and me: hugely.

\section{Monica Kidd MD}

Family Medicine, University of Calgary, Calgary, Alta.

This is a true story; however, patient details have been changed to protect identities.

CMAJ 2015. DOI:10.1503/cmaj.141611

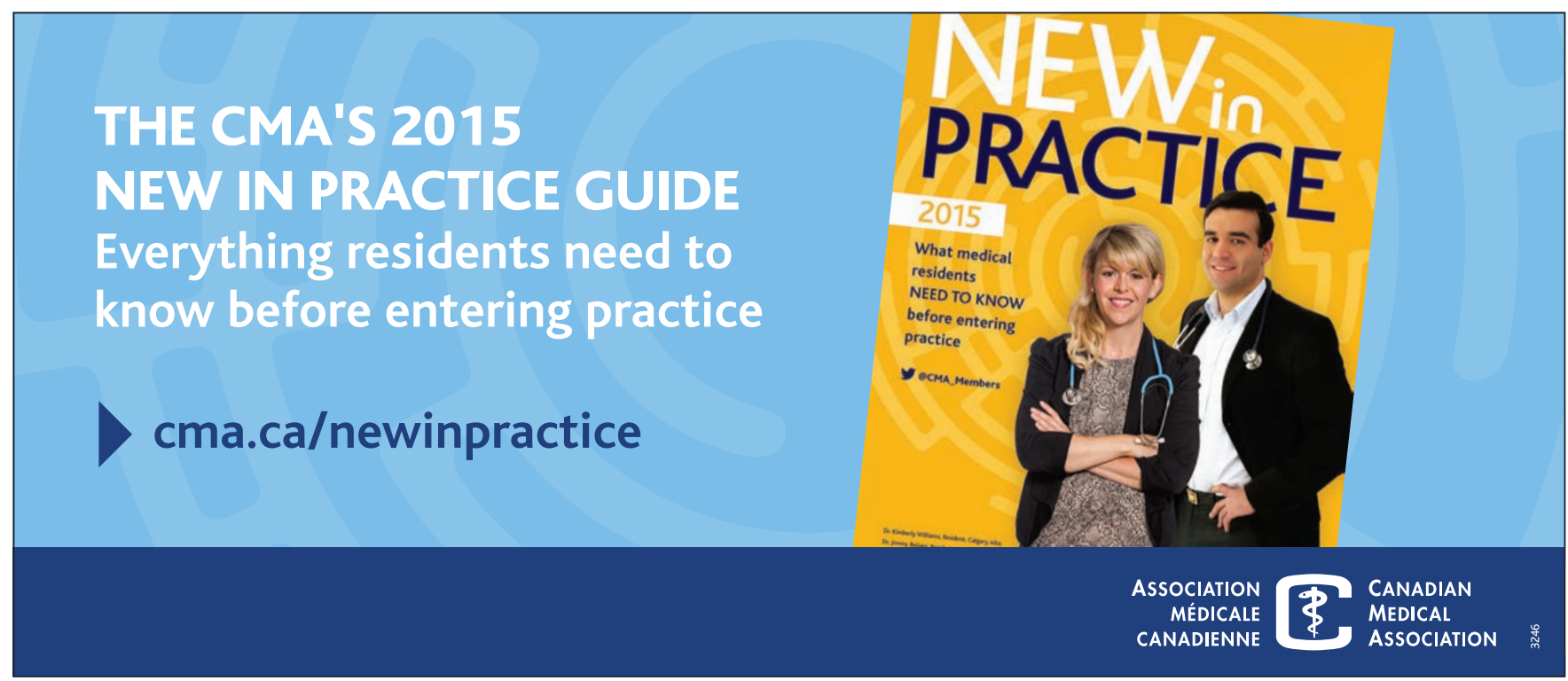

